\title{
Asanas in Prone Posture and Slow Pranayamas Can Prevent Respiratory Complications in COVID-19 Patients
}

\author{
Gopal Krushna Pal ${ }^{1, *}$, Nivedita Nanda ${ }^{2}$
}

\section{Gopal Krushna Pal ${ }^{1, *}$ Nivedita Nanda ${ }^{2}$}

'Department of Physiology and Programme Director, Advance Center for Yoga, JIPMER, Puducherry, INDIA. ${ }^{2}$ Department of Biochemistry, JIPMER, Puducherry, INDIA.

\section{*Correspondence}

\section{Dr. Gopal Krushna Pal}

Editor-in-Chief, IJCEP, Professor (Senior Scale), Department of Physiology and Programme Director, Advance Center for Yoga, JIPMER, Puducherry, INDIA.

Phone: +91-9344291160

Email: drgkpal@gmail.com

\section{History}

- Submission Date: 31-08-2020;

- Review completed: 13-09-2020;

- Accepted Date: 25-09-2020.

DOI : 10.5530/ijcep.2020.7.3.22

Article Available online

http://www.ijcep.org

\section{Copyright}

(C) 2020 Phcog.Net. This is an openaccess article distributed under the terms of the Creative Commons Attribution 4.0 International license.
Worldwide more than 31 million have been reported till date to suffer from corona virus disease 2019 (COVID-19) and daily about ninety thousand positive cases are reported from India alone. About $10 \%$ of all symptomatic COVID-19 patients present with dyspnoea, interstitial pneumonia and few may progress to acute respiratory distress syndrome (ARDS) and multiorgan dysfunction. ${ }^{[1]}$ It has been reported that most common cause of mortality in COVID-19 is the acute respiratory failure. Though antiviral drugs, chloroquine or hydroxychloroquine and respiratory therapies are being used, there are several ongoing clinical trials on traditional medicines for development of new therapies and vaccines, till date there is no evidence of any effective treatment for COVID-19. Prone positioning has been used as an effective therapy in ARDS, particularly when initiated in the early stage of it. ${ }^{[2]}$ Recent reports have suggested improvement in respiratory functions of COVID-19 patients with prone positioning. ${ }^{[3]}$ Based on postures in which asanas are practiced, they are divided into standing asanas, sitting asanas, supine asanas and prone asanas. ${ }^{[4]}$ As prone positioning facilitates pulmonary functions, it is expected that prone asanas will promote respiratory functions. The practice of chandranadi pranayama (left-nostril breathing) and anulom-vilom pranayama (alternatenostril breathing) has been demonstrated to have maximum beneficial effects on autonomic and cardiorespiratory functions. ${ }^{[5,6]}$ Pal's slow pranayama schedule that comprises of both chandranadi and anulom-vilom pranayama's has been documented to be effective in preventing ventricular tachycardia by improving vagal tone by modulating the process of respiratory sinus arrythmia. ${ }^{[7]}$ Therefore, we assume that practice of asanas in prone posture and slow pranayama will improve cardio-respiratory functions in COVID-19, especially if practiced in the early phase of the disease.The asana-pranayama schedule could be as given below. Following eight asanas in prone posture as described in yoga book, ${ }^{[4]}$ can be practiced:
i) Ardha-shalabhasana (half-locust pose): $2 \mathrm{~min}$.
ii) Shalabhasana (locust pose): $2 \mathrm{~min}$
iii) Bhujangasana (cobra pose): $2 \mathrm{~min}$
iv) Sphinx asana: $3 \mathrm{~min}$
v) Makarasana (Crocodile pose): $3 \mathrm{~min}$
vi) Jyestikasana (superior posture): $3 \mathrm{~min}$

vii) Matsya kridasana (flapping fish pose): $5 \mathrm{~min}$.

viii) Advasana (reversed corpse-pose or opposite shavasana): $5 \mathrm{~min}$

Pranayama schedule: The patient can practice slow breathing pranayama (both chandranadi and anulom-vilom), ${ }^{[5,6]}$ or the procedure as described in Pal's pranayama schedule, ${ }^{[7]}$ in which one cycle of pranayama consists of two rounds of slow chandranadi pranayama followed by one round of alternate nostril breathing. About 10 cycles of this pranayama can be practiced in one schedule.

The asana-pranayama schedule may be performed once in the morning and once in the evening, each session lasting about $45 \mathrm{~min}$. During other time, patient may lie-down on the bed in matsya-kridasana or adavasana, whenever he/she find it comfortable. A PDF file of pictures and a video of the entire practice session can be sent to the mobile phone (WhatsApp/ Telegram App/ e-mail) of the patient. Though there are many prone asanas, we prefer only those abovementioned asanas that a COVID-19 patient can perform. Further, these asanas help in strengthening the muscles of neck, thoracic cage and abdominal wall and facilitate the functioning of respiratory apparatus. ${ }^{[8]}$

As slow nostril breathing with increased duration of expiration has been reported to promote vagal tone while improving the sympathovagal balance, ${ }^{[9]}$ the increased duration of expiration in Pal's slow pranayama schedule will further potentiate the vagal tone. Increased vagal tone is known to improve oxygenation and pulmonary functions in hypoxic human beings. ${ }^{[10]}$ Further, in slow breathings, the more expansion of chest wall and increased afferent discharge from thoracic cage and lungs will improve the vagal control of the breathing.

It has been documented that SARS-CoV-2 virus targets two genes, Angiotensin converting enzyme 2 (ACE2) and Transmembrane protease, serine 2 (TMPRSS2) that are widely distributed in cells of respiratory tract, which encodes the main receptor protein to enter the human cells. ${ }^{[11]}$ Studies have revealed that both ACE2 and TMPRSS2 are expressed by cells in the olfactory epithelium that houses olfactory sensory neurons and a variety of supporting cells. It is further observed that two specific cells that include sustentacular cells, which wrap around sensory neurons and are thought to
Cite this article: Pal GK, Nanda N. Asanas in Prone Posture and Slow Pranayamas Can Prevent Respiratory Complications in COVID-19 Patients. Int J Clin Exp Physiol. 2020;7(3):89-90. 
provide structural and metabolic support to the neurons and the basal cells, which act as stem cells that regenerate the olfactory epithelium after damage, express both ACE2 and TMPRSS2 genes. Also, it has been proposed that SARS-CoV-2 does not directly infect neurons but may instead interfere with brain and other neurological functions by affecting vascular cells in the neural tissues. ${ }^{[12]}$ As slow pranayamas improve blood supply and oxygenation of the organs, it is expected that the vascular functions of the respiratory system and functions of cells of mucosal epithelium of respiratory tract will be improved by Pal's pranayama and this will prevent the SARS-CoV-2 virus to affects the cells of respiratory system.

It is reported that fear, nervousness, anxiety and sleep disorders are common in COVID-19 patients. $^{[13]}$ Therefore, we expect that asanapranayama practice will not only prevent respiratory complications in COVID-19 patients, but also will prevent development of psychosomatic distress in them.

\section{REFERENCES}

1. Yang $X, Y u Y, X u$ J, Shu H, Xia J, Liu H, et al. Clinical course and outcomes of critically ill patients with SARS-CoV-2 pneumonia in Wuhan, China: A singlecentered, retrospective, observational study. Lancet Resp Med. 2020;8:475-81.

2. Golestani-Eraghi M, Mahmoodpoor A. Early application of prone position for management of Covid-19 patients. J Clini Anesth. 2020;66:109917.

3. Cohen D, Wasserstrum Y, Segev A, Avaky C, Negru L, Turpashvili N, et al. Ben- eficial effect of awake prone position in hypoxaemic patients with COVID-19: case reports and literature review. Intern Med J. 2020;50(8):997-1000.

4. Saraswati SS. Asanas: In: Asana pranayama mudra bandha. $4^{\text {th }}$ Edition. Munger, Bihar: Yoga Publication Trust. 2002;2-11.

5. Bal BS. Effect of anulom vilom and bhastrika pranayama on the vital capacity and maximal ventilatory volume. J Phys Educ Sport Manag. 2010;1(1):11-5.

6. Singh S, Gaurav V, Parkash V. Effects of a 6-week nadi-shodhana pranayama training on cardio-pulmonary parameters. J Phys Educ Sport Manag. 2010;2(4):44-7.

7. Pal GK. Disappearance of ventricular ectopics following 15-day practice of Pal's pranayama schedule. Int J Clin Exp Physiol. 2018;5(2):105-7.

8. Chanavirut R, Khaidjapho K, Jarce P, Pongnaratorn P. Yoga exercise increases chest wall expansion and lung volumes in young healthy Thais. Thai J Physiol Sci. 2006;19(1):1-7.

9. Pal GK, Agarwal A, Karthik S, Pal P, Nanda N. Slow yogic breathing through right and left nostril influences sympathovagal balance, heart rate variability and cardiovascular risks in young adults. North Am J Med Sci. 2014;6(3):145-51.

10. Ito S, Sasano H, Sasano N, Hayano J, Fisher JA, Katsuya H. Vagal nerve activity contributes to improve the efficiency of pulmonary gas exchange in hypoxic humans. Exp Physiol. 2006;91(5):935-41.

11. Bilinska K, Jakubowska P, Bartheld CSV, Butowt R. Expression of the SARSCoV-2 entry proteins, ACE2 and TMPRSS2, in cells of the olfactory epithelium: Identification of cell types and trends with age. ACS Chem Neurosci. 2020;11(11):1555-62.

12. Brann DH, Tsukahara T, Weinreb C, Lipovsek M, DenBerge K, Gong B, et al. Non-neuronal expression of SARS-CoV-2 entry genes in the olfactory system suggests mechanisms underlying COVID-19-associated anosmia. Sci Adv. 2020;6(31):eabc5801.

13. Balachandar V, Mahalaxmi I, Subramaniam M, Kaavya J, Kumar NS, Gracy L. Follow-up studies in COVID-19 recovered patients: Is it mandatory?. Sci Total Environ. 2020;729:139021.

Cite this article: Pal GK, Nanda N. Asanas in Prone Posture and Slow Pranayamas Can Prevent Respiratory Complications in COVID-19 Patients. Int J Clin Exp Physiol. 2020;7(3):89-90. 